\title{
Field characteristics and petrography of the advanced rifting-related Triassic submarine basaltic blocks in the Jurassic mélange of the Darnó Unit
}

\author{
Gabriella Kiss, Ferenc Molnár \\ Department of Mineralogy, Faculty of Sciences \\ Eötvös Loránd University, Budapest
}

\author{
Sándor Kovács† \\ Geological, Geophysical and Space Science \\ Research Group of the Hungarian Academy of \\ Sciences, Budapest
}

Ladislav A. Palinkaš

Department of Mineralogy and Petrology,

Faculty of Science, University of Zagreb, Zagreb

\begin{abstract}
The Darnó Unit in NE Hungary contains basalt and associated sediments related to the advanced rifting stage of Triassic age in the Neotethys. A detailed field study of five key outcrops and two deep wells revealed that only distal facies of basaltic lava flows of submarine volcanoes occur as blocks in the Jurassic mélange; the central and the most distal facies are missing. The advanced rifting-related Triassic and oceanic stage-related Jurassic basalt flows of the same mélange can be distinguished on the basis of lithostratigraphic, structural and textural features. The paper contains for the first time the detailed description of the key outcrops of peperitic facies consisting of a mixture of basalt and red micritic limestone. The occurrence of this facies is the principle key feature for discrimination in the field between Triassic and Jurassic basalt. In addition, four types of Triassic basalt were recognized: the Báj-patak-type, the Mély Valley-type, the Nagy-Rézoldal-type and the Reszél Hill-type. The observed peculiarities of advanced rift-related basalt are also compared to characteristics of volcanics encountered in wells drilled in the Darnó Unit. This comparison solves many problems of earlier interpretations of the studied wellbore sections.
\end{abstract}

Key words: Submarine volcanic facies, peperites, petrography, Triassic basalt; advanced rifting, Neotethys

\section{Introduction}

Several studies have dealt with the submarine basaltic rocks of the Darnó Unit (e.g. Papp 1938; Mezősi and Grasselly 1949; Kiss 1958; Buda and Kiss 1980; Balla et al. 1980; Kubovics 1984; Balla 1987; Kubovics et al. 1990; Dosztály and Józsa 1992; Józsa 1999; Kovács et al. 2008, among others) and they arrived at

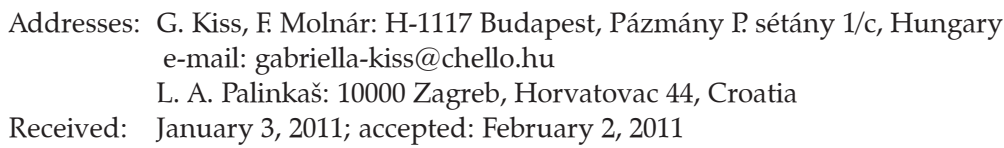


controversial conclusions concerning the origin of these rocks. However, many of the authors recognized their specific characteristics as differing from the midoceanic ridge basalts, sensu stricto, and from their equivalent, Jurassic basalt, occurring nearby in the Szarvaskő Unit of the Bükk Mts.

A similar origin and possible relationship between these submarine basaltic rocks and occurrences in the Dinarides were recognized on the basis of stratigraphy, petrochemistry and tectonic evolution of the region (Downes et al. 1990; Harangi et al. 1996; Józsa 1999; Haas and Kovács 2001; Palinkaš et al. 2008). Recognition of the occurrence of volcanic units with peperitic facies called the attention again to this area and the most recent studies imply convincingly that the formation of these basaltic rocks is related to the Triassic advanced rifting stage within the Neotethyan realm (Kiss et al. 2008; Kovács et al. 2008; Haas et al. 2010; Kovács et al. 2010; Kiss et al. 2011). The intercalation of basaltic pillow lava with carbonate sediment (i.e. the peperitic facies) is the unique key feature of the advanced rift-related Neotethyan basaltic units because limestone-bearing peperite does not occur in true oceanic ophiolite; however, this facies is easy to recognize in the field (Kiss et al. 2008; Palinkaš et al. 1998, 2008).

Although several studies were published dealing with this region, none of them contained a detailed description of the key exposures of the Triassic basaltic units in the Darnó Hill area. One of the major aims of this paper is to provide descriptive information about those localities. Comparison of the surface outcrops with volcanic suites found in two deep wells is another important aspect and novelty of the present paper.

\section{Previous studies and regional geology}

The Darnó Unit is a part of the Bükk Unit, that is, an element of the Pelso Composite Unit (Fig. 1). The approximately $7 \mathrm{~km}^{2}$-large area can be interpreted as a continuation of the structural elements of the nappe system of the Bükk Unit (Kovács et al. 2008). The lowest unit is the "Bükk Parautochton", which contains Paleozoic to Jurassic formations. The Mónosbél Unit, above it, is made up mainly of Jurassic redeposited slope sediments. The Szarvaskő Unit contains an incomplete Jurassic ophiolite-like sequence associated with deep-sea sediments. The Darnó Unit is made up of Triassic and Jurassic submarine volcanites and related sediments (Csontos 1999; Haas and Kovács 2001; Kovács et al. 2008).

In the first half of the 20th century, intensive studies were carried out on the Darnó basalt, since native copper and other ores were found in the area (Papp 1938; Mezősi and Grasselly 1949; Kiss 1958). Understanding of the geologic setting of the area, however, was not the focus of the contemporaneous studies. Kiss (1958) published the detailed petrography of the basalt of the Hosszú Valley without discrimination among the different kinds of basalt.

Two decades later, in 1977-79 (related to the exploration of the Recsk copper ore deposit), several 1,200 m-deep wells have again drawn attention to the geology 


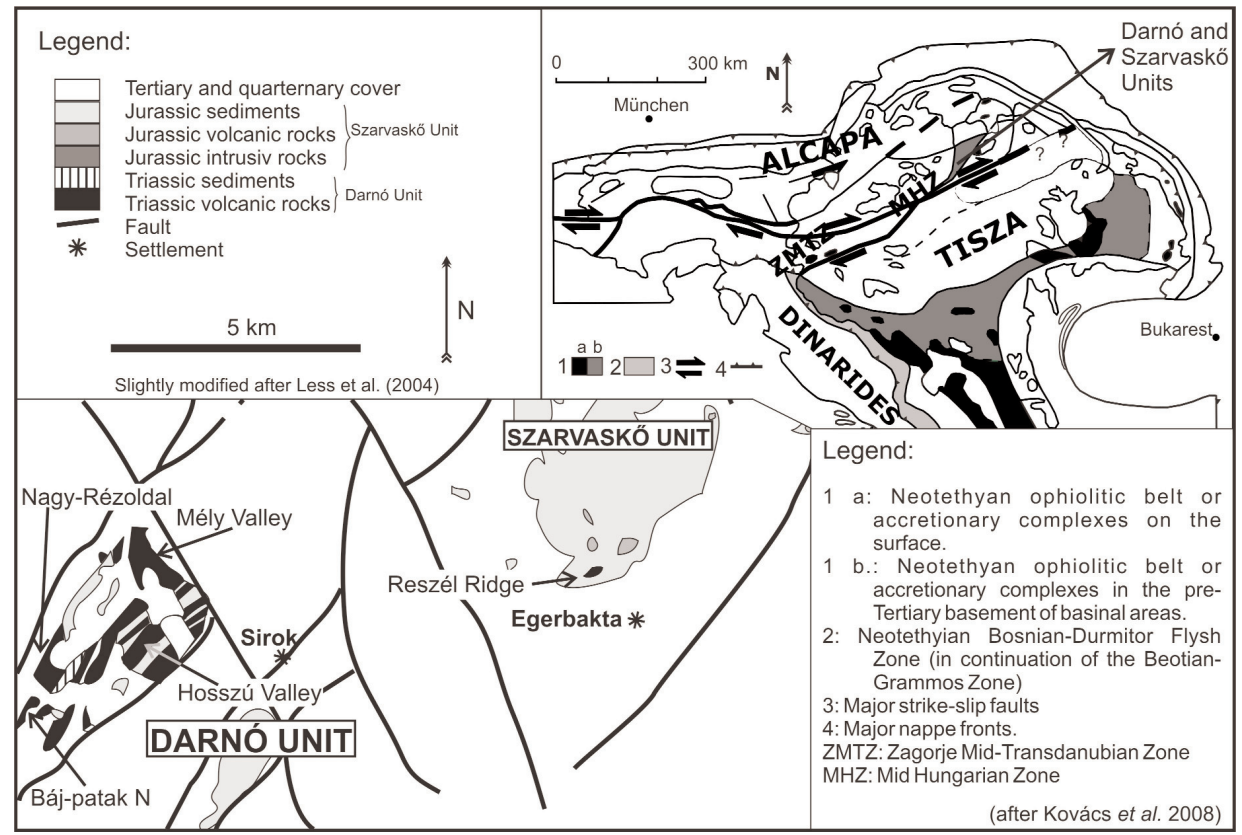

Fig. 1

Structural sketch map of the Circum-Pannonian region and the geologic sketch map of the Darnó Unit. The studied quarries are shown on the map

of the Darnó Unit. The study of the rocks in the cores of wells Rm-131, -135 and -136 confirmed typical oceanic characteristics of the volcanites (Balla et al. 1980). The lithostratigraphic succession, with sediment complexes below magmatic rocks, was interpreted as an overturned sequence. The authors suggested a spreading-related origin and not a mid-oceanic ridge environment. On the other hand, Dosztály and Józsa (1992) proposed mid-oceanic ridge-related magmatism and suggested that the age of the Darnó basalt was Triassic rather than Jurassic. Based on detailed studies of the cores Józsa (1999) suggested the existence of an ocean from the Triassic, which reopened as a back-arc-basin in the Middle Jurassic. Different types of basalt (e.g. plagioclase rich or poor) were distinguished, the presence of some pyroxene was shown and observations concerning the occurrence of alteration and hydrothermal minerals (calcite, quartz, prehnite, pumpellyite, chlorite, zeolite...) were made. However, the most recent interpretation suggests that both the Mónosbél Unit and the Darnó Unit can be found in the subsurface and that the magmatic rocks (both Triassic and Jurassic) occur as large olistoliths in the mélange (Kovács et al. 2008).

Buda and Kiss (1980), on the basis of re-examination of the cores as well as of field studies, invoked early rifting-related origin of the magmatic complex in Middle to Late Triassic times. The latter idea was supported by Kubovics (1984), 
who came to this conclusion after finding petrographic evidence for relatively shallow marine alteration. According to Downes et al. (1990) the Darnó basalt is of Triassic age and it shows petrographic and geochemical features significantly different from those of the (Jurassic) Szarvaskó basalt and was possibly formed as an oceanic island or on the continent margin. Harangi et al. (1996) proposed that these magmatic rocks form olistoliths in an olistostrome sequence; they bear ophiolite-like characteristics and represent parts of the Triassic ophiolitic sequence of the Meliata Ocean. In contrast, Haas and Kovács (2001), Dimitrijevic et al. (2003), Kovács et al. (2008) and Palinkaš et al. (2008) correlated the geology of the Darnó Hill area with the northwestern part of the Dinarides. The advanced rifting-related origin was proven and more correlation aspects were shown by Kiss et al. (2008), Kiss et al. (2011), and Kovács et al. (2010). A Triassic age of some magmatic olistoliths in the Jurassic mélange was also confirmed by radiolarian biostratrigraphy (Gawlick et al. 2010). Correlation with similar basaltic units in the Dinarides-Hellenides by Kiss et al. (2008) and Kiss et al. (2011) has also shown that the Triassic basaltic blocks represents different facies of submarine lava flows in the subsiding rifting basin.

\section{Proximal and distal volcanological facies of submarine basaltic lava flows around eruption centers}

Descriptions of the different volcanological facies occurring in quarries of the Darnó Unit were made on the basis of comparison with a complete submarine basaltic mound of Triassic age described by Palinkaš et al. (1998; 2000, 2008) in the Hruškovec quarry (Kalnik Mts, Croatia). An advanced rifting-related Triassic basalt unit is exposed in the Hruškovec quarry, where six different volcanological facies were distinguished within the submarine cryptodome, which can reach ca. $2 \mathrm{~km}$ of diameter (Fig. 2).

In the center, coherent pillow lava occurs, which represents the main feeder zone of the extrusion. The bending rims around the massive core, $30-50 \mathrm{~cm}$ thick, are dissected by polygonal columnar joints radiating from the center, formed by the cooling of the basalt. No inter-pillow hyaloclastite breccia occurs in this facies as no magma-water interaction happened at the time of solidification of basalt.

The coherent pillow facies is surrounded by the closely-packed pillow lava facies with some hyaloclastite breccia among the pillows. This facies forms when the lava cools off rapidly, so chilled glass surrounds the densely packed lobes. The amount of the inter-pillow hyaloclastite breccia increases as a function of distance from the center of the cryptodome. Hydrothermal infillings, such as amygdales, jig-saw veins and former feeding channels can occur in this facies. Pyjama-type pillow is a subtype of this facies. The spherical pillow lava balls, $\mathrm{dm}-\mathrm{m}$ in size, grown and chilled in isostatic state (diminished density contrast) within water-soaked sediment, are named after peculiar alternating basaltic shelves within the sphere, encrusted with white hydrothermal minerals. Thus 


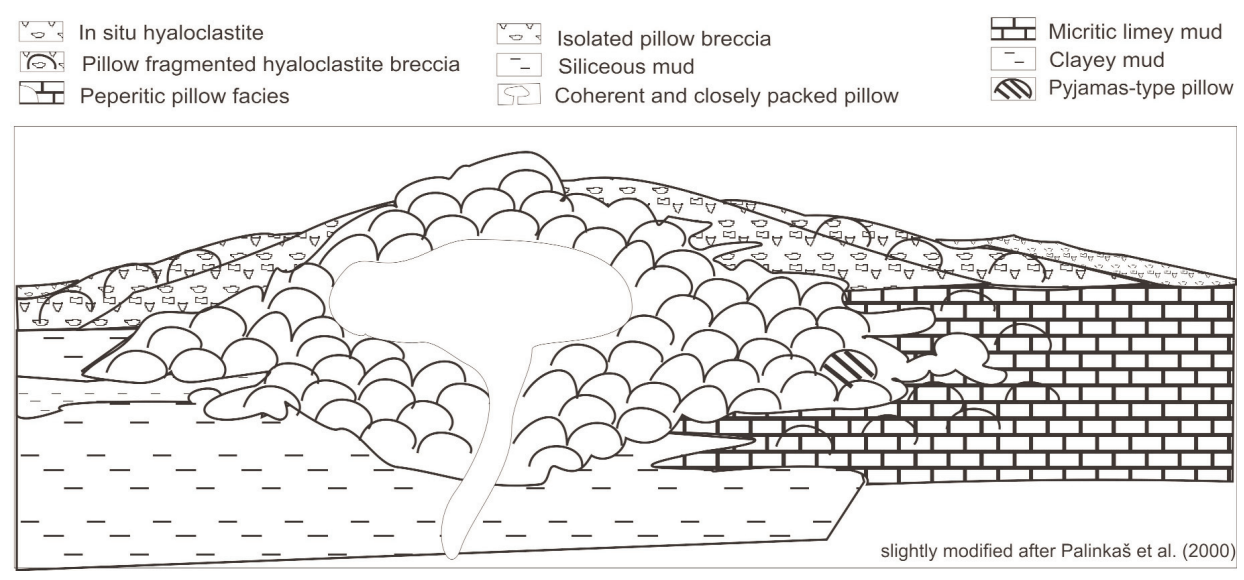

Fig. 2

Sketch of the facies architecture of a submarine basaltic lava flow (not to scale)

this type of pillow (together with the peperitic facies; see below) indicates that the lava flow was propagating within the unconsolidated sediment rather than on the sea-floor; however, the pyjama-style pillows are geopetal structures.

Where the lava entered the water-soaked sediment, blocky and globular peperitic facies formed. In this facies the basalt mingles with the sediment: the unconsolidated carbonate mud infiltrated into the cooling cracks of the basalt and mixed with the hyaloclastite breccia. However, larger, semi-consolidated blocks can also be found in this type of breccia in the form of anhedral clasts.

On the sea floor, around the closely packed pillows, very rapid cooling took place in the seawater; in situ hyaloclastite, then pillow-fragmented hyaloclastite and finally isolated pillow breccia developed, as a function of distance from the closely-packed pillow facies. All of these types contain mainly pieces of basalt lobes and glassy shards, cemented by hydrothermal minerals. The in situ hyaloclastite contains less cement and larger fragments untill the isolated pillow breccia contines the smallest amount of basalt.

\section{Methods}

Field studies were carried out in 5 basalt quarries of the Darnó Unit. However, a 200 m-long part of the core from well Rm-136 (from 200 to $400 \mathrm{~m}$ ), as well as a $300 \mathrm{~m}$-long part of the core from well Rm-131 (from 500 to $800 \mathrm{~m}$ ), both containing basaltic volcanic suites among sediments, were also studied. Petrography of samples with emphasis on texture of rocks and hydrothermal alteration was carried out on polished thin sections. To complement the polarized microscopic observations the X-Ray Powder Diffraction (XPD) method was used to determine some mineral phases, using a Siemens D-5000 type equipment, with 
Bragg-Brentano geometric diffractometer emission $(\Theta-\Theta$ working method, $\mathrm{Cu}$ $\mathrm{K} \alpha(\lambda=0.154178 \mathrm{~nm}))$, secondary graphite crystal monochromator and scintillation detector. The interpretation of the data was carried out using EVA software.

\section{Description of the key outcrops of peperitic basalt in the Darnó Unit}

The outcrops of the peperitic basalts in North Hungary, exposed by quarrying, enabled the study of the four facies (from the above-mentioned 6 facies of the Kalnik Mts) the closely-packed pillows, the peperitic pillows, the in situ hyaloclastite and the pillow-fragment hyaloclastite breccia.

\section{Báj-patak quarry}

The Báj-patak quarry (presently under recultivation) is situated south of the Darnó Hill, about $4 \mathrm{~km}$ east of Recsk, close to the Eger-Recsk road (nr. 24.; N 47.9222 / E 20.1387). This quarry exposes the most typical peperitic succession in the Darnó Unit; however, different blocks of closely packed pillow and some blocks of in situ hyaloclastite breccia also occur (Fig. 3A-C).

The northeastern part of the amphitheater-shaped quarry accommodates closely packed pillow blocks. The greyish-green pillows in this unit are characterized by jig-saw veins (Fig. 3D). In some places, even the youngingupward setting of the pillows is well expressed. In the central part of the quarry, well-observable spherulites on the outer rims of the pillows, as well as smaller and larger amygdales are also present in this facies. Microscopically mainly variolitic texture outlined by the arrangements of the plagioclase laths can be observed. In the marginal parts of the pillows spherulitic unite in their center sometimes even intersertal textures occur. There are 0.5-2 mm-large knots which are characterized by an abundance of pyroxene laths (Fig. 8A-B). The $0.5-3 \mathrm{~mm}-$ thick jig-saw veins are filled with calcite, chlorite and pyrite. The smaller amygdales are 1-3 $\mathrm{mm}$ in diameter and are filled with calcite and chlorite. The larger amygdales are 5-15 $\mathrm{mm}$ in size and are filled with calcite and pyrite.

The in situ hyaloclastite breccia facies occur in the central and northeastern parts of the quarry. In the central part there is a continuous facies change from the closely-packed pillow through the in situ hyaloclastite breccia to the peperitic facies. In the case of this facies change, first more and more breccia occurs between the smaller pillows and finally this becomes a true hyaloclastite breccia. The basaltic fragments reach sizes of up to $20-30 \mathrm{~cm}$ and the cement contains glassy shards, calcite, chlorite and pyrite.

Fig. $3 \rightarrow$

A) Panorama picture of the Báj-patak quarry, taken in 2009 (part 1). B) Panorama picture of the Bájpatak quarry, taken in 2009 (part 2). C) Sketch of the facies of the Báj-patak quarry (white letters show the places where photos D and E were taken). D) Pillow with jig-saw veins from the closely-packed facies. E) Peperitic facies in the Báj-patak quarry. Green basalt mingles with red micritic limestone 
Rifting-related Triassic submarine basaltic blocks in the Jurassic mélange of the Darnó Unit, Hungary 187
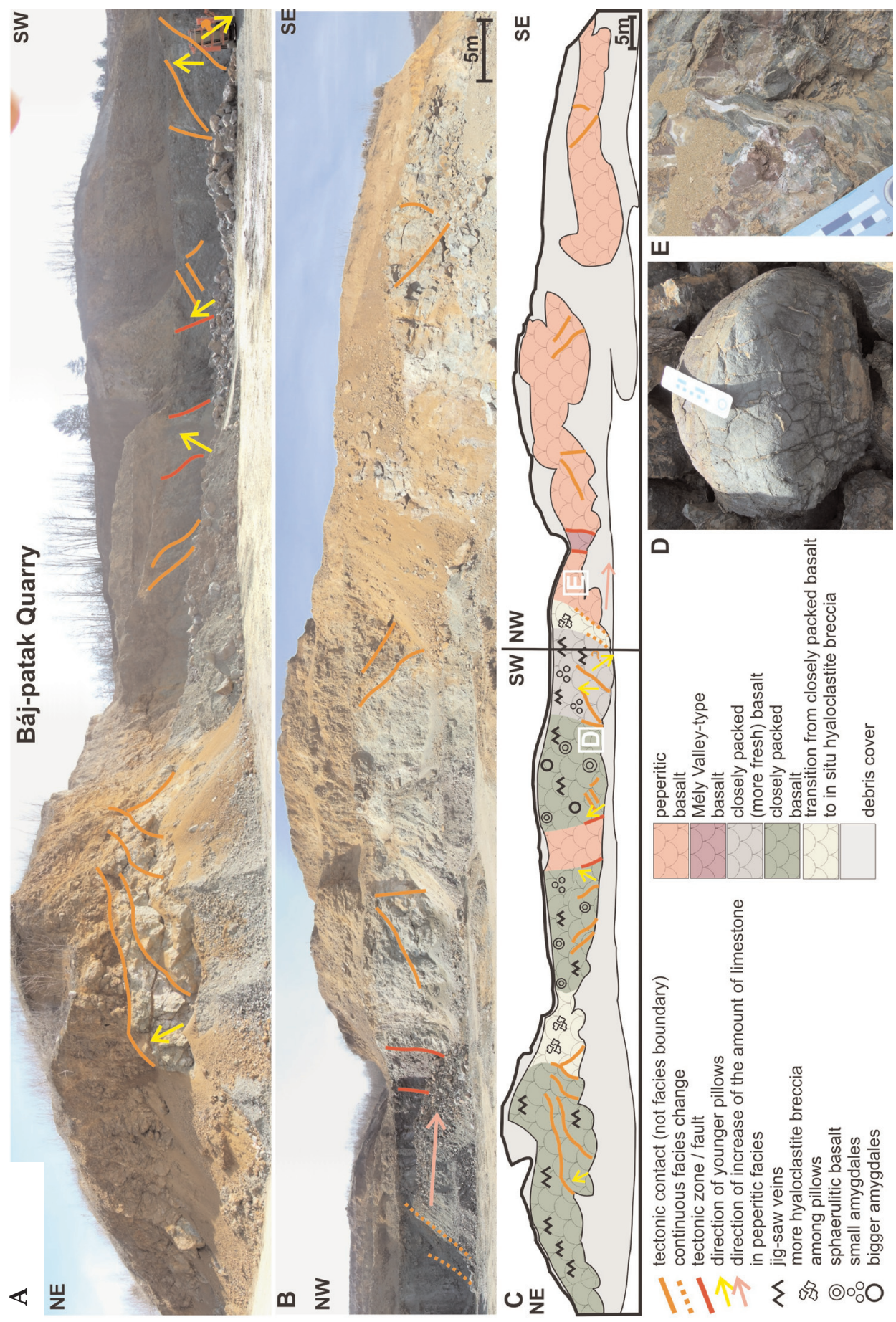

Central European Geology 53, 2010 
A small block of reddish amygdale-bearing basalt surrounded by reddish sedimentary matrix occurs in the central part of the quarry. The basalt is characterized by variolitic texture with $30-40 \%$ microcrystalline hematitized groundmass occurring among the plagioclase laths. The 1-3 mm-large amygdales are mainly filled with calcite and some chlorite.

Large blocks representing the peperitic facies also occur in the quarry. In this facies, greenish basalt mingles with red limestone (Fig. 3E). The same micritic carbonate material occurs in cavities and veins within the basalt and in the interpillow hyaloclastite breccia. In some places the basalt is much more altered, probably because of the stronger fluid circulation along chilling fissures and cracks. Calcite-filled veins and amygdales occur in the basalt, while shorter veins are common in the limestone as well. At some places basalt fragments can also be found in the limestone.

\section{Hosszú Valley q}

The Hosszú Valley quarry is situated in the middle of Darnó Hill, at about a $3 \mathrm{~km}$ walk from the Eger-Recsk (nr. 24) road (N 47.9322 / E 20.1598). The quarry exposes various blocks of the closely-packed pillow facies, but pillow-fragmented hyaloclastite breccia, dolerite and some red radiolarite layers also occur at its northeastern end. The mélange character of the exposed rocks is clearly evidenced by a small block of highly tectonized rock in the middle of the quarry, in which Triassic and Jurassic basalt and sedimentary rocks are mixed (Fig. 4A-B).

The reddish and reddish-grey basalt blocks (Fig. 4C-D) are tectonically displaced relative to each other; in addition, sometimes even the direction of younger pillows is different, but their textures are very similar, varying from spherulitic to variolitic-intersertal ones. Skeletal crystals of plagioclase are hosted by a microcrystalline, chlorite and hematite-bearing groundmass. Calcite-chlorite pseudomorphs after olivine phenocrysts are also common. The 0.1-3 mm-large amygdales (Fig. 4F) are filled with calcite, chlorite, quartz and hematite. The same filling is found in the $0.2-2 \mathrm{~mm}$-thick veinlets and veins, with addition of prehnite and pumpellyite. In the southwestern part of the quarry even the socalled pyjama-type pillow occurs: this rock type contains $1-2 \mathrm{~cm}$-thick bands of calcite, quartz, hematite and laumontite. The small amount of hyaloclastite breccia among the pillows refers to the closely packed pillow facies (Fig. 4E). The breccia contains mainly glass shards, up to $5 \mathrm{~cm}$ in size, while the cementing material is mainly calcite with some chlorite.

Fig. $4 \rightarrow$

A) Panorama picture of the Hosszú Valley quarry, taken in 2008. B) Sketch of the facies of the Hosszú Valley quarry. C) Pyjama-type pillow from the southwestern end of the quarry (white letters show the places where photos D-G were taken). D) Lava lobes in the closely-packed pillow facies. E) Interpillow hyaloclastite breccia in the closely-packed pillow facies. F) Small amygdales in the closelypacked pillow, from the middle of the quarry. G) Pillow-fragmented hyaloclastite breccia from the northeastern part of the quarry 
Rifting-related Triassic submarine basaltic blocks in the Jurassic mélange of the Darnó Unit, Hungary 189

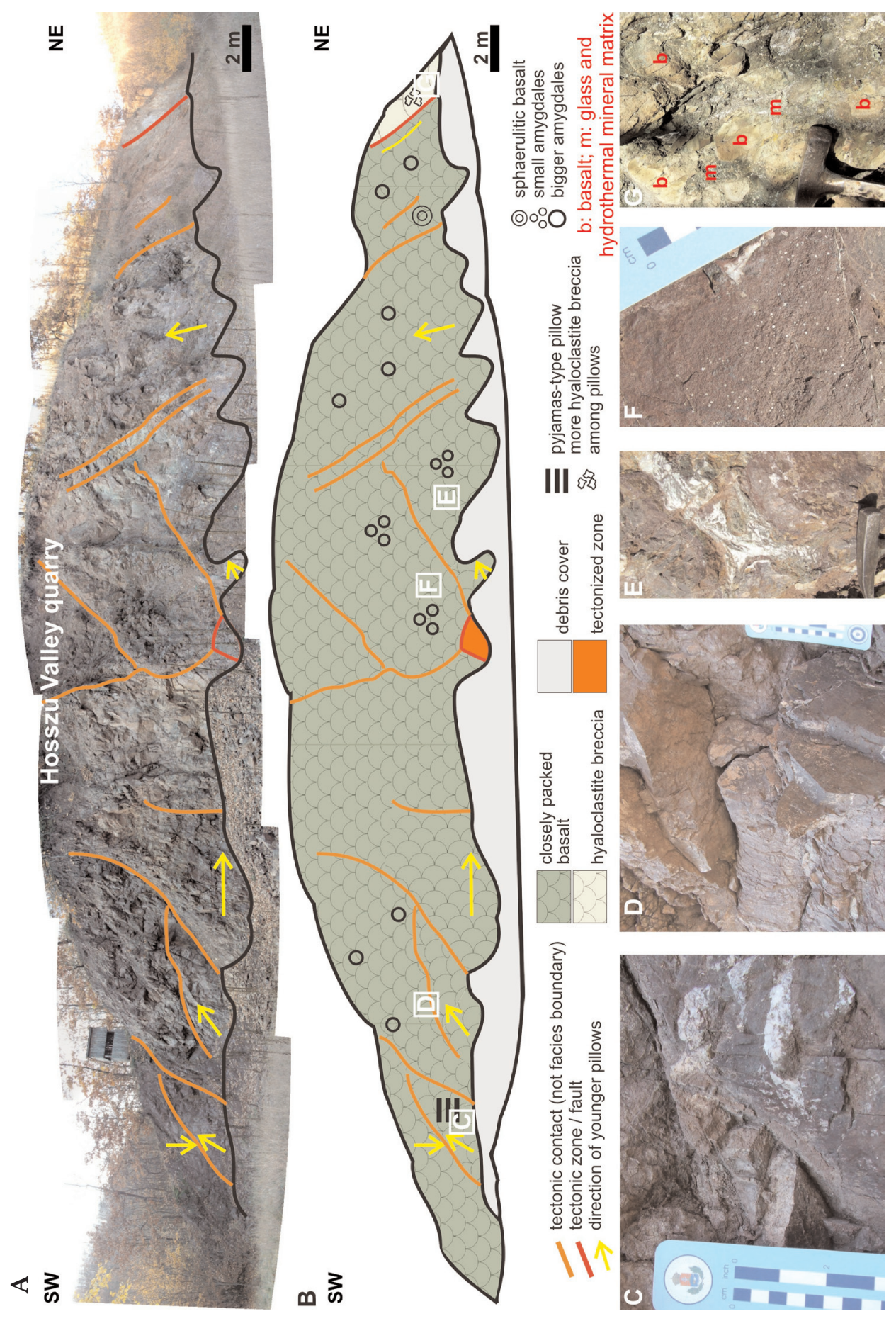

Central European Geology 53, 2010 
The pillow fragmented hyaloclastite breccia (Fig. 4G) contains up to $10 \mathrm{~cm}$ large greenish, glassy basalt clasts and up to $3 \mathrm{~cm}$-large glassy shards, while its cement consists of quartz, chlorite, calcite and prehnite.

At the northeastern edge of the quarry (not shown on the panorama picture), strongly tectonized pillow-fragmented hyaloclastite breccia, red radiolarite and a block of dolerite (possibly the deeper feeder zone of the basalt) is also exposed.

The small tectonized block in the center of the quarry looks like a peperitic block (basalt mingled with fine-grained siliciclastic sediment and not with limestone), but thin section examination proved that it is a polymict breccia containing clasts of the country rocks (Jurassic basalt, Triassic basalt, siltstone, Jurassic gabbro, etc.). It is strongly hematitized, probably because of the more intense shearing in comparison to the other parts of the quarry. The block can be interpreted as an evidence of tectonic mélange formation.

\section{Mély Valley quarry}

The Mély Valley quarry is situated in the northeastern part of Darnó Hill, about $3 \mathrm{~km}$ SE of the village of Szajla (N 47.9495 / E 20.1641). It exposes a mélange made of Triassic basalt and sediment-bearing blocks thrust over a Jurassic sedimentary succession (shale, radiolarite) (Fig. 5A-B). The quarry has two levels: the upper level exposes mainly tectonized radiolarite and some basalt, whereas Jurassic grey radiolarite, Triassic red radiolarite and basaltic rocks, even with peperites, can be found at the bottom level. The age of the pillow basalt succession is Triassic, proven by radiolarians found in a radiolarite block mingled with the basalt (Gawlick et al. 2010) (Fig. 5C), while the occurrence of Jurassic radiolarite in the host sediments can indicate the age of the mélange. As the quarry was mined until 2007, almost all of the good-quality basalt was excavated and only cracked, amygdale- and other hydrothermal infill-bearing basalt and sedimentary rocks remained in the locality.

Two different volcanological facies were recognized in the Mély Valley quarry: the closely-packed pillow with feeding channels, amygdales and even pyjamatype infill (Fig. 5D-E) and the peperitic pillow facies.

At the southern end of the quarry, amygdales, feeding channels and veins are common in the red, hematitized basalt. The basalt shows clear pillow structure, but after mining ended this type was found mostly as debris and some blocks were left in the wall only. Microscopically the basalt is glassy and contains up to $60 \%$ microcrystalline-chloritic material with fine-grained hematite and rare

Fig. $5 \rightarrow$

A) Panorama picture of the Mély Valley quarry, taken in 2007. B) Sketch of the facies of the Mély Valley quarry (white letters show the places where photos C, D and E were taken). C) Jurassic grey radiolarite and shale in clear tectonic contact with a block of red Triassic rocks; basalt mingled with radiolarite. Triassic radiolarite was found in this block, so the age of this basalt is also Triassic. D) Calcite-filled amygdales and feeding channel in a lava lobe from the closely-packed pillow facies. E) Pyjama-type pillow 
Rifting-related Triassic submarine basaltic blocks in the Jurassic mélange of the Darnó Unit, Hungary 191

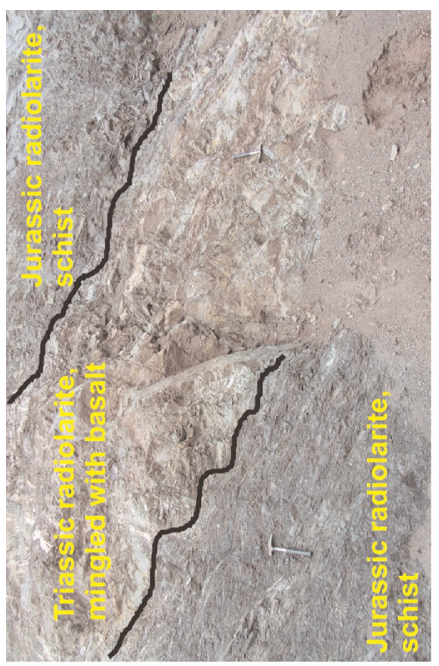

u

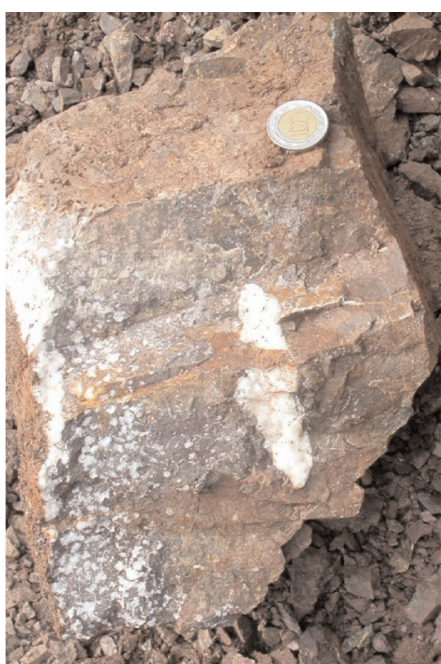

口

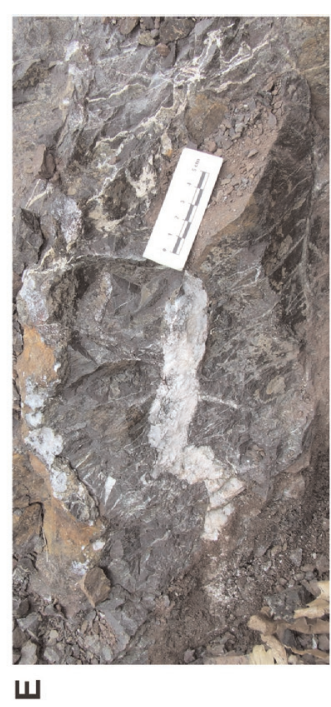

ш

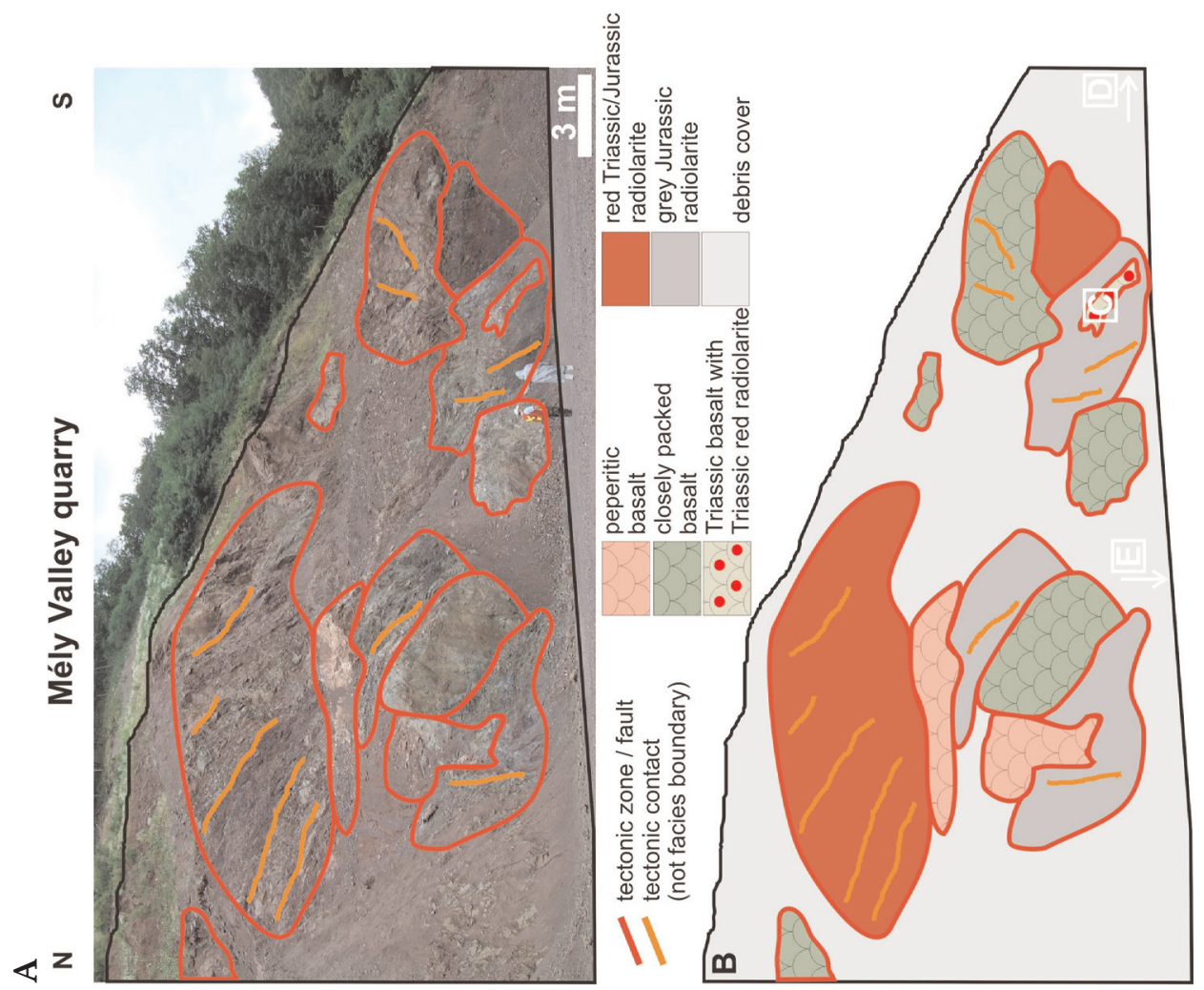

Central European Geology 53, 2010 
pyrite. Arrangements of the skeletal crystals of plagioclase outline the spheruliticvariolitic texture of the rock. Calcite-chlorite pseudomorphs after olivine and porphyric plagioclase also occur beside rock-forming plagioclase (Fig. 8C). The diameter of amygdales varies between $1 \mathrm{~mm}$ and $8 \mathrm{~mm}$. They are filled with calcite and a small amount of quartz-chalcedony. The 0.4-0.8 mm-thick, short veins usually radiate out from the amygdales and they mainly contain calcite, but quartz, chlorite and occasionally epidote, prehnite and pumpellyite can also occur within them. A small amount of hyaloclastite breccia occurs among the pillows, in which the glassy basalt shards are cemented mostly by calcite, but epidote, chlorite, hematite, prehnite and quartz also occur in the cement.

In the middle of the quarry, a block with pyjama-type pillow was also found. The mineral bands are up to 3-4 cm thick, filled mainly with calcite, chlorite and hematite. The basalt bands are microscopically similar to the other basalt types of the quarry; however, $0.2-0.8 \mathrm{~mm}$-thick veins filled with calcite, quartz, chlorite, and epidote are more abundant in it.

Some peperitic blocks occur next to the closely-packed pillow unit with some pyjama-type pillows. This blocky peperite contains irregular to rounded basalt fragments and lava lobe fragments (texturally similar to the other basalt types of the quarry described above) hosted in a red limestone matrix. The diameter of fragments and lava lobes is from $10 \mathrm{~cm}$ to $50 \mathrm{~cm}$. The amount of the limestone matrix is less than $50 \%$ (Kiss et al. 2011).

\section{Nagy-Rézoldal quarry}

The Nagy-Rézoldal quarry is situated in the western part of Darnó Hill, about $3 \mathrm{~km}$ east of Recsk (N 47.9273 / E 20.1353). It is easily accessible from the EgerRecsk road (nr. 24). Mainly blocks of greenish and greenish-grey basalt are exposed in the quarry, though smaller blocks of possibly Jurassic sedimentary rocks (representing an olistostrome mélange, e.g. radiolarite, shale, sandstone) can be found at its northern edge as well. The basalt blocks are in tectonically disturbed contact with each other and at places even the directions of the younger pillows are different in these adjoining blocks. Almost all blocks represent the closely-packed pillow facies, with sub-types distinguished clearly. One block of pillow-fragmented hyaloclastite breccia is found in the middle of the quarry (Fig. 6A-C).

Pillows contain amygdales of variable size (from 0.2 to $8 \mathrm{~mm}$ ) and jig-saw veins in the various sub-types (Fig. 6D-E). In some places well observable spherulites can be seen on the pillows' surfaces with naked eye. Microscopically the texture varies between the spherulitic, variolitic and intersertal types. Beside the

Fig. $6 \rightarrow$

A) Panorama picture of the Nagy-Rézoldal quarry, taken in 2007 (part 1), B) Panorama picture of the Nagy-Rézoldal quarry, taken in 2007 (part 2), C) Sketch of the facies of the Nagy-Rézoldal quarry (white letters show the places where photos D and $\mathrm{E}$ were taken), D) Closely-packed pillow with jigsaw veins, E) Closely-packed pillow rich in small amygdales 
Rifting-related Triassic submarine basaltic blocks in the Jurassic mélange of the Darnó Unit, Hungary 193
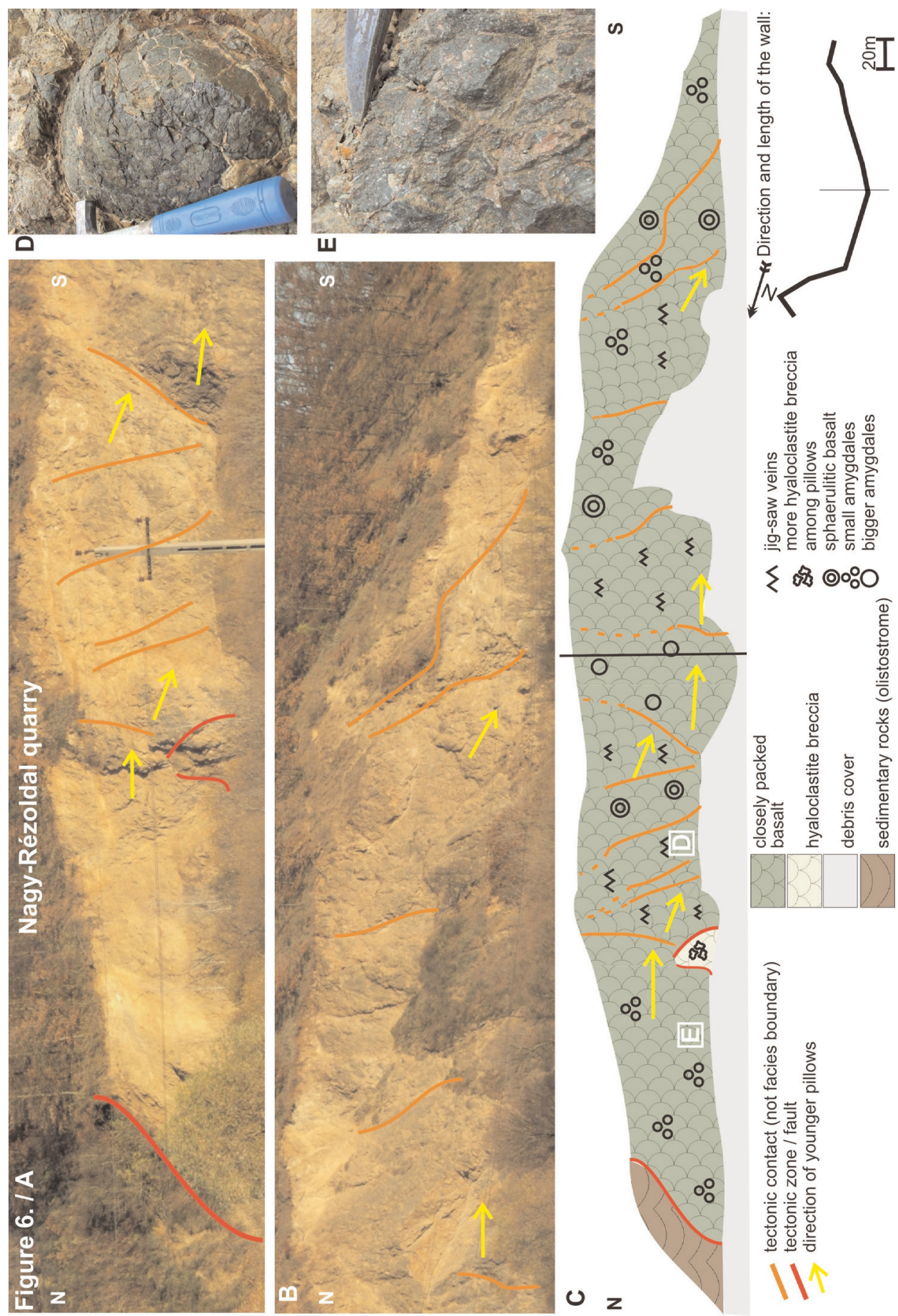

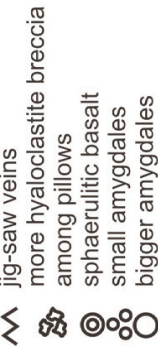
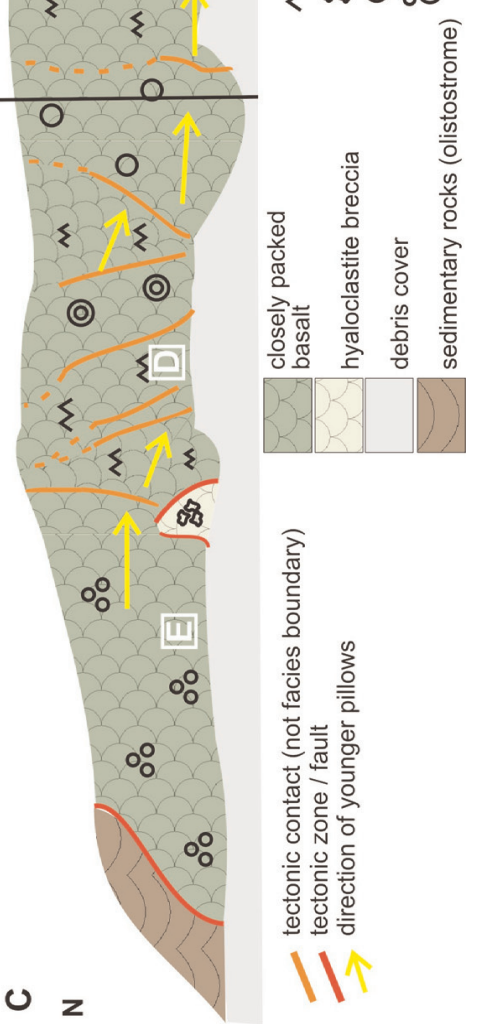

Central European Geology 53, 2010 
microcrystalline-chloritized groundmass, phenocrysts of plagioclase as well as pyroxene laths (Fig. 8E) and calcite-chlorite pseudomorphs after olivine occur in the basalt. The $0.2-0.8 \mathrm{~mm}$-thick cross-cutting veinlets and the $1-3 \mathrm{~mm}$ thick jigsaw veins are filled with calcite and a small amount of chlorite, quartz, prehnite, and pumpellyite. The smaller $(0.2-2 \mathrm{~mm})$ amygdales are filled with chlorite, chalcedony, and calcite, whereas the larger $(2-8 \mathrm{~mm})$ ones contain mainly calcite with some quartz and chlorite.

A 5 m-large block of pillow-fragmented hyaloclastite breccia occurs in the middle of the quarry. The large basaltic fragments, up to $30 \mathrm{~cm}$ in size, are mixed with strongly hematitized, glassy-chloritized material. The matrix is mainly calcite but some chlorite is also presented.

\section{Reszél Hill quarry}

Another excellent example of the mélange complex is exposed in the Reszél Hill quarry, situated about $2 \mathrm{~km} \mathrm{NW}$ of the village of Egerbakta and about $10 \mathrm{~km}$ from Darnó Hill, next to the Egerbakta-Bátor road (N 47.9455 / E 20.277). The eastern part of the quarry exposes a greyish, closely-packed pillow block. The block is in tectonic contact with Jurassic sedimentary rocks (Mónosbél Formation) to the west. A block of peperitic pillow facies follows the closely-packed pillow unit further to the west. In the westernmost part of the quarry, pillowfragmented hyaloclastite and in situ hyaloclastite breccia is in tectonic contact with a Jurassic limestone block (Oldalvölgy Formation; Fig. 7A-B).

The closely-packed pillow (Fig. 7D) consists of about 30\% microcrystalline matrix containing chlorite, fine-grained hematite, rarely pyrite and chalcopyrite. In thin sections arrangements of the skeletal crystal plagioclase laths provides the generally variolitic texture of the rock. Calcite-chlorite-hematite pseudomorphs after olivine also occur in the rock (Fig. 8G). The sparse, $0.2-0.8 \mathrm{~mm}$-thick veins and the $0.8 \mathrm{~mm}$-large rare amygdales are filled with calcite and chlorite. The closely-packed pillow unit also contains pyjama-type infill (Fig. 7C). Its hydrothermal bands are $2-2.5 \mathrm{~cm}$ thick and contain mainly calcite with a small amount of hematite. This phenomenon is a convincing geopetal structure and clearly shows the younging setting of the pillows (Kiss et al. 2008). Small amounts of hyaloclastite breccia occur among the pillows. In the breccia the $0.5-2 \mathrm{~cm}$-large basaltic and glassy shards are cemented by calcite and chlorite. Westward macroscopically well-observable spherulites are common on the pillows' surface.

The peperitic facies forms a single block of about $15 \mathrm{~m}$ within the sedimentary matrix of the Jurassic mélange (Fig. 7E); the Jurassic sediments do not show

Fig. $7 \rightarrow$

A) Panorama picture of the Reszél Hill quarry, taken in 2006. B) Sketch of the facies of the Reszél Hill quarry (white letters show the places where photos C-F were taken). C) Pyjama-type pillow from the eastern end of the quarry. D) Closely-packed pillow showing clearly the direction of the younger pillow (yellow arrow). E) Peperitic facies, where red limestone was mingled with the basalt. F) In situ hyaloclastite breccia with many large basalt fragments from the western end of the quarry 
Rifting-related Triassic submarine basaltic blocks in the Jurassic mélange of the Darnó Unit, Hungary 195
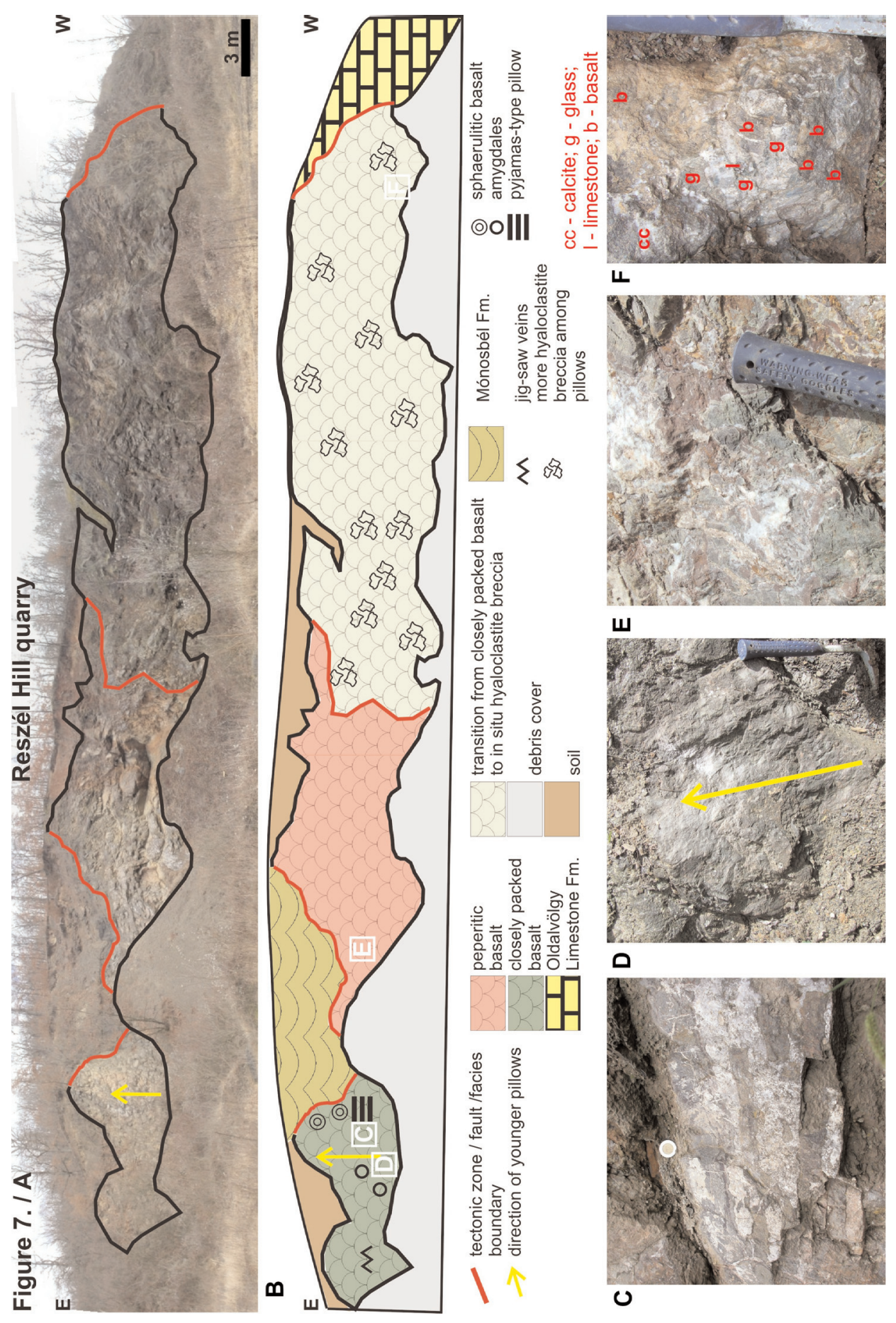

Central European Geology 53, 2010 

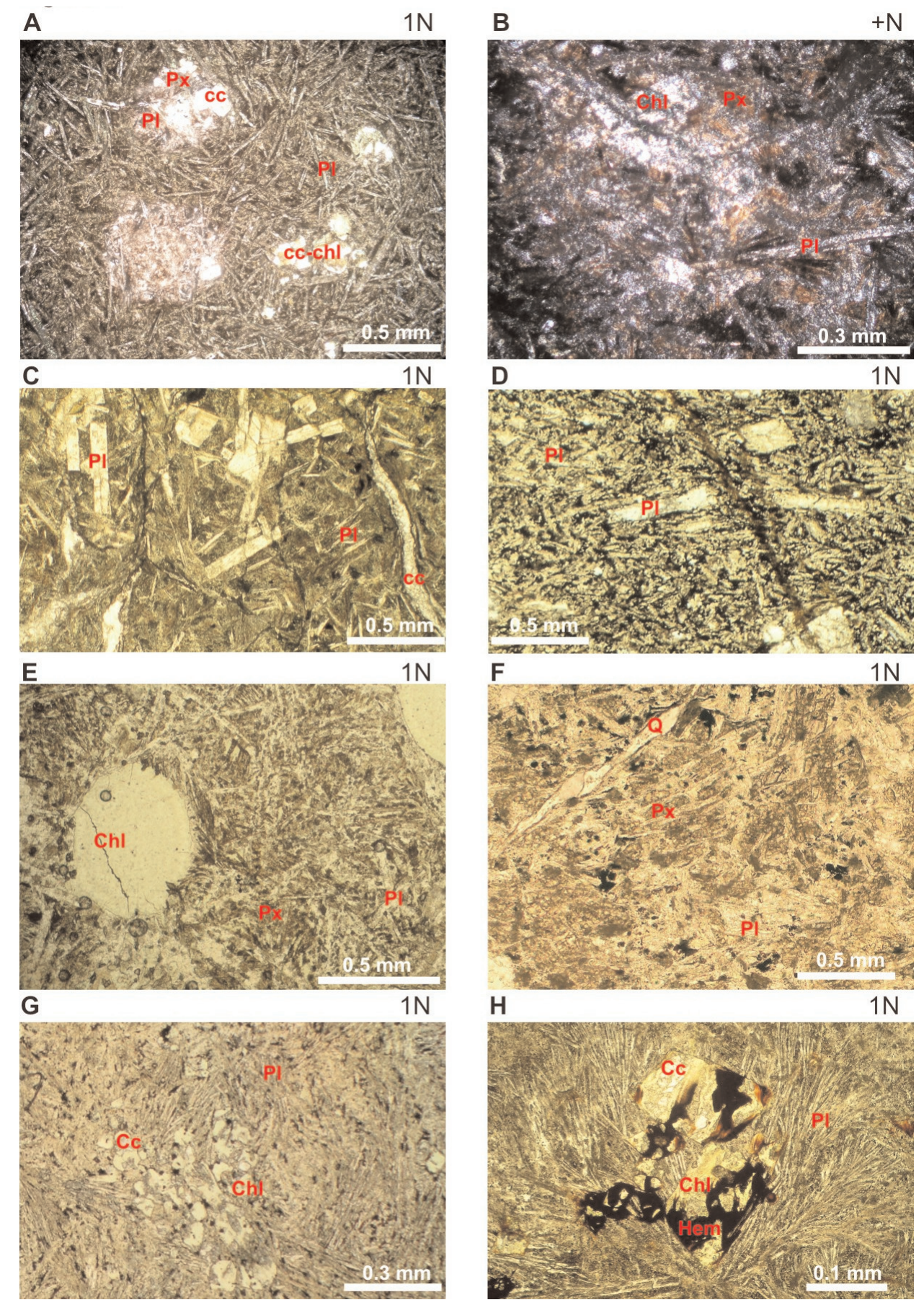

Central European Geology 53, 2010 
thermometamorphic alteration along the contact with the volcanic rocks (Kiss et al. 2011). In this so-called blocky peperite, not only up to $50 \mathrm{~cm}$-large micritic limestone and basalt fragments can be observed, but the mingling of the two components also occurs. However, beside calcite and pumpellyite, red limestone can also be found in the cross-cutting veins of the basalt as well.

The hyaloclastite breccia shows a clear tectonic contact with the peperitic facies; nevertheless the place of origin was close to the limestone-bearing part of the submarine extrusion. Beside the up to 20-30 cm-large basaltic clasts and the smaller, 2-5 cm-large glassy shards, up to $1 \mathrm{~cm}$ large limestone fragments occur in the hydrothermal mineral (calcite, chlorite, pyrite, hematite)-cemented breccia. An in-situ hyaloclastite unit can be observed at the western part of this block (Fig. 7F). This environment is characterized by larger pillow and lava lobe fragments, while passing continuously into pillow fragmented hyaloclastite breccia eastward within the quarry.

\section{Basaltic rocks in deep wells}

Following detailed re-examination of the magmatic series in the cored deep wells, no new unit boundaries were observed in relation to the earlier published core logs (Balla et al. 1980; Józsa 1999). The more detailed section, however, enabled comparison with the surface outcrops and detailed subdivision of the volcanic facies.

A $300 \mathrm{~m}$ long part and some samples from other parts of the Rm-131 core were studied. In this part of the core (from $500 \mathrm{~m}$ to $800 \mathrm{~m}$ ), mainly basalt, various shale levels and some limestone occur. The lithotypes are separated by $10-50 \mathrm{~cm}$-thick, strongly tectonized zones (Fig. 9). Most of the basalt blocks are classified into two major groups:

Group A: reddish-gray variolitic-spherulitic basalt with 1-3 mm-thick calcitechlorite veinlets and rare 1-3 mm large calcite-chlorite-epidote amygdales. These

$\leftarrow$ Fig. 8

A-B) Typical intersertal texture from a Báj-patak-type basalt. Lighter "knots" occur in the basalt, where no chlorite occurs in the groundmass; however, small pyroxene (augite) laths can be found. Calcitechlorite pseudomorphs after olivine also occur $(1 \mathrm{~N},+\mathrm{N}$; locality: Báj-patak quarry; the more fresh basalt block in the middle of the quarry). C) Typical (but a bit glassy) intersertal texture of a Mély Valley-type Triassic basalt. Plagioclase in two size groups can be seen; therefore some porphyric characteristic can be observed (1N; locality: Mély Valley quarry, basalt block from the southern part of the quarry). D) Mély Valley-type basalt from core Rm-131, $792 \mathrm{~m}$. (1N). E) Typical intersertal texture of a Nagy-Rézoldal-type basalt. Pyroxene laths are common among plagioclase crystals. (1N; locality: Nagy-Rézoldal quarry, middle of the quarry). F) Nagy-Rézoldal-type basalt from core Rm-131, $692 \mathrm{~m}$ (1N). G) Typical variolitic texture of a Reszél Hill-type basalt. Beside plagioclase, calcite-chlorite-filled pseudomorphs after olivine are common (1N; locality: Reszél Hill quarry, next to the pyjama-type pillow). H) Reszél Hill-type basalt from core Rm-136, $222 \mathrm{~m}$. Calcite-chlorite-filled pseudomorphs after olivine occur. The sample is more hematitized. $(1 \mathrm{~N})$. (Abbreviations used: cc - calcite; chl chlorite; hem - hematite; pl - plagioclase; px - pyroxene) 


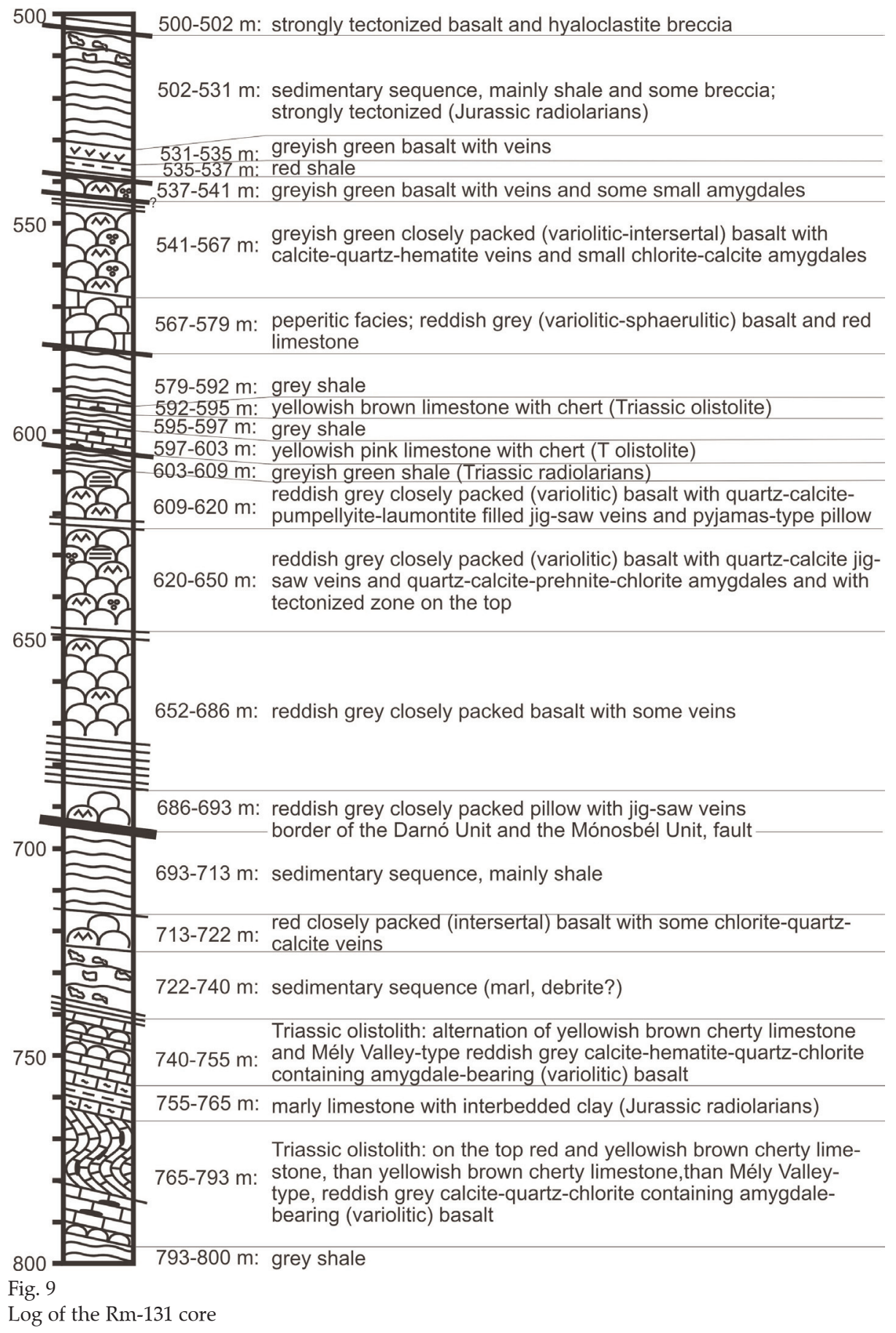


blocks occur from $537 \mathrm{~m}$ to $567 \mathrm{~m}$, from $609 \mathrm{~m}$ to $620 \mathrm{~m}$ (possibly to $650 \mathrm{~m}$ ), and from $713 \mathrm{~m}$ to $722 \mathrm{~m}$ in the cored hole. The microcrystalline groundmass is often hematitized and beside plagioclase, calcite-chlorite-serpentinite pseudomorphs after olivine are common. In some places the pillow structure of the basalt is evident and occurrences of inter-pillow hyaloclastite breccia suggests the closelypacked pillow facies. Pyjama-type infilling also occurs together with the rare amygdales and the more common jig-saw veins.

Group B: reddish basalt with variolitic texture and 0.5-1 cm-large amygdales. This type of basalt occurs from $740 \mathrm{~m}$ to $755 \mathrm{~m}$ and from $790 \mathrm{~m}$ to $793 \mathrm{~m}$ in the cored well. In the microcrystalline groundmass, plagioclase of two size groups and calcite-chlorite pseudomorphs after mafic minerals are included (Fig. 8D). The amygdales and veinlets are filled with calcite, quartz, chlorite and hematite. Very similar basalt occurs together with red limestone at $295.7 \mathrm{~m}$ and $371.0 \mathrm{~m}$.

From $567 \mathrm{~m}$ to $579 \mathrm{~m}$, beside the reddish basalt, which mingles with limestone, a chaotic mixture of different kinds of rocks can be found. This can be interpreted as a result of tectonic movements and thus pieces of different blocks are represented here. It consists of strongly altered fragments, such as relicts of sedimentary rocks, as well as reddish and greenish basalt varieties. The equivalents to the greenish basalt occur at depths of $234.1 \mathrm{~m}, 239.0 \mathrm{~m}$, and 476.5 $\mathrm{m}$. This basalt is characterized by a variolitic texture and contains pyroxene laths beside abundant plagioclase, and small $(0.5-3 \mathrm{~mm})$ calcite-chlorite-filled amygdales also occur, with some veins filled with the same hydrothermal minerals (Fig. 8F).

At $256.6 \mathrm{~m}$, grey basalt with dark knots and calcite-containing veinlets is present. This rock has a different appearance from that described above, as it has 1-3 mm-large knots without chlorite in the groundmass (though the groundmass contains chlorite around these knots).

A $200 \mathrm{~m}$-long part (from $200 \mathrm{~m}$ to $400 \mathrm{~m}$ ) of the Rm-136 core was also studied. In this part of the core, basalt is the predominant rock, but some blocks of limestone, radiolarite and shale also occur. The different rock units are separated by thick, strongly tectonized zones (Fig. 10). Three major types of basalt (with two subtypes in group A) were distinguished in this section:

Group A/1: from $200 \mathrm{~m}$ to $205 \mathrm{~m}$, pillow-fragmented hyaloclastite breccia with greenish-gray and sometimes reddish-gray, 10-20 cm-large basaltic clasts and glassy fragments cemented by calcite, quartz, chlorite, prehnite and hematitebearing matrix.

Group A/2: greenish-grey and reddish-green, 1-3 mm-thick jig-saw veincontaining basalt, which occurs from $205 \mathrm{~m}$ to $251 \mathrm{~m}$, from $258 \mathrm{~m}$ to $270 \mathrm{~m}$ and from 300 to $305 \mathrm{~m}$ in the well. The veins are filled with calcite, chlorite and rarely epidote, while the rare small amygdales contain calcite only. The basalt has a spherulitic-variolitic texture and beside the plagioclase laths, some pyroxene and calcite-chlorite pseudomorphs after olivine occur in the rock (Fig. 8H). Pyjamatype infill (calcite, hematite, chlorite) is present sporadically. Inter-pillow 
Figure 10.

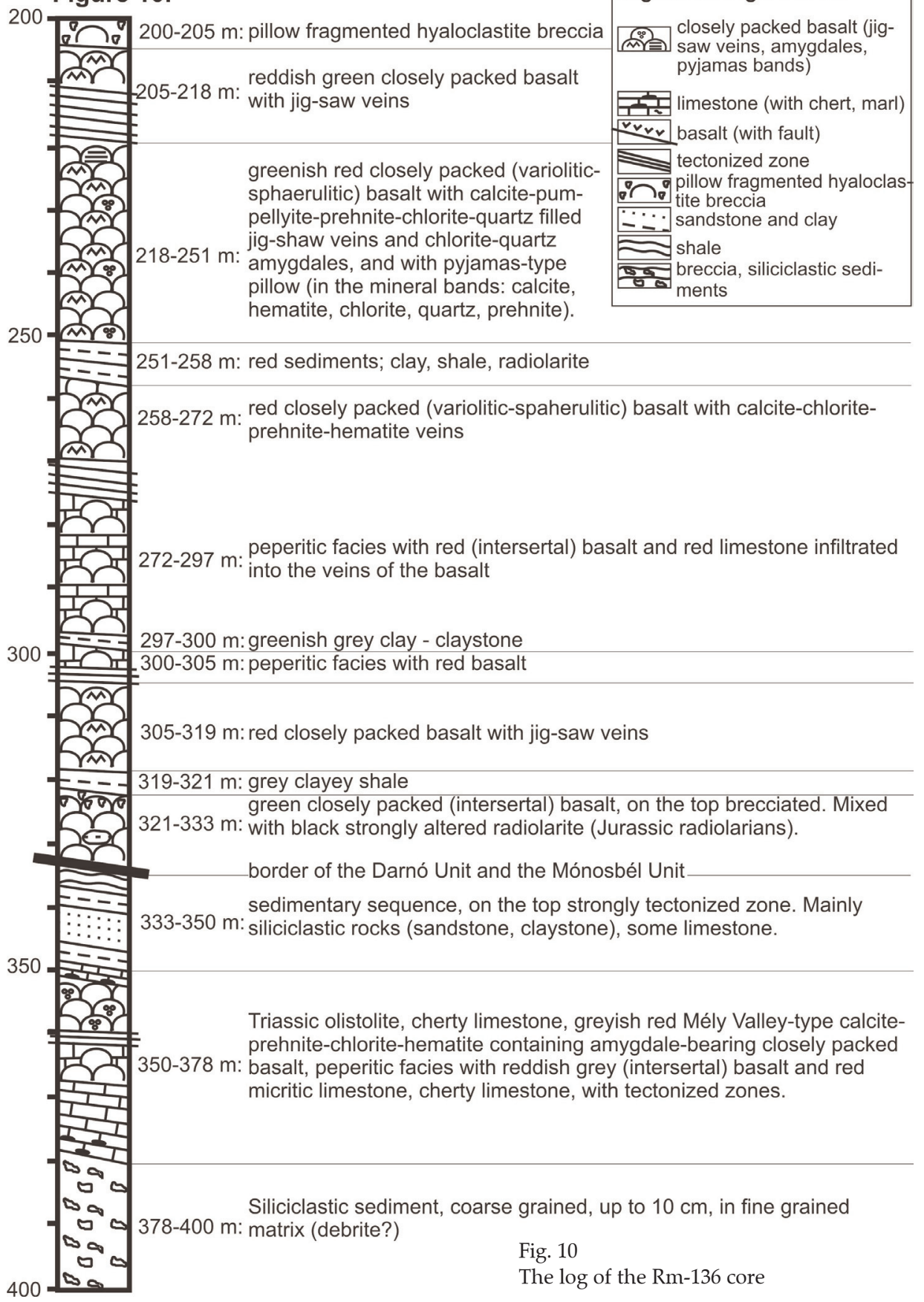


hyaloclastite breccia and clearly visible pillow structure indicate that these blocks represent the closely-packed pillow facies.

Group B: from $352 \mathrm{~m}$ to $370 \mathrm{~m}$, two blocks of reddish grey basalt occur in a Triassic olistolith. The basalt is mingled with reddish micritic limestone, so the blocks represent the peperitic facies. The basaltic rock is characterized by intersertal texture and contains a small amount of microcrystalline material, as well as plagioclase laths in two size groups and calcite-chlorite-prehnite pseudomorphs after olivine. The $0.3-1 \mathrm{~cm}$-large amygdales are filled with calcite, chlorite and hematite.

Group C: from $325 \mathrm{~m}$ to $333 \mathrm{~m}$, a completely different type of basalt occurs in the well. Green basalt mingles with black, formerly sedimentary (now completely altered) material. The basalt is characterized by intersertal texture. In the microcrystalline matrix, coarser-grained plagioclase (in comparison to the samples described above) and euhedral to subhedral pyroxene (possibly augite) occur. This block is assigned a Jurassic age based on radiolarians found in less altered parts of the black sedimentary rocks.

\section{Discussion: comparison of the basaltic suites}

The results of detailed and comparative studies in quarries and deep wells of the Darnó Unit show that the closely-packed pillow facies occurs in every locality, whereas the peperitic facies is present in the Báj-patak, Mély Valley and Reszél Hill quarries only. The in situ hyaloclastite breccia occurs at the Báj-patak and the Reszél Hill quarries and the pillow-fragmented hyaloclastite breccia was detected in the Hosszú Valley, the Nagy-Rézoldal and the Reszél Hill quarries only. In the cores closely-packed pillow, pillow-fragmented hyaloclastite breccia and peperitic facies were found. This leads to the conclusion that all of these occurrences represent distal parts of submarine lava flows. The coherent pillow facies, which is postulated as a diagnostic feature of the central part of a submarine basaltic extrusion, was not recognized in the Darnó Unit. However, the most distal facies, the isolated pillow breccia is also missing.

Basalt of the Darnó Unit can be classified into 4 groups: The Mély Valley-type basalt is characterized by an abundance of large amygdales, red or reddish-grey in color, abundant hematite in the groundmass and generally two size groups of plagioclase. The Reszél Hill-type basalt is characterized by grey, greenish-gray, and sometimes reddish-grey color, occurrence of both chlorite and hematite in the groundmass and occurrences of pyrite and chalcopyrite. Amygdales and veins are relatively rare, but pyjama-type pillow occurs in the sequence. The Nagy-Rézoldal-type basalt is usually green because of the high amount of chlorite in the groundmass and beside plagioclase, small laths of pyroxene also occur. However, amygdales of variable size and jig-saw veins are common. The Báj-patak-type basalt is characterized by grey or greenish-grey color and an abundance of pyrite and chlorite patches in the groundmass. Chlorite is common 
in the groundmass; however, knots containing pyroxene and plagioclase without chlorite are also usual.

Basalt occurrences of the Hosszú Valley quarry can be classified partly into the Mély Valley-type and partly into the Reszél Hill-type. In the Báj-patak quarry a block of Mély Valley-type rock occurs in addition to the predominant Báj-pataktype basalt. In the cores all of the above-mentioned types are represented: group A in each core belongs to the Reszél Hill-type, group B to the Mély Valley-type, while the green basalt of core Rm-131 corresponds to the Nagy-Rézoldal-type and the grey one represents the Báj-patak-type basalt.

The Triassic age of some of these basalt occurrences is proven by radiolarian biostratigraphy (Dosztály and Józsa 1992; Gawlick et al. 2010, etc.), others may also be assumed to be Triassic as they show similarities in macroscopic and microscopic characteristics, and strong genetic relationships on the basis of their petrochemistry (Kiss et al. 2011). Our observations suggest that a volcanologicaltextural classification can be established for Triassic basalt and this classification may help to distinguish these rocks from the Jurassic basalt occurring in the same mélange. The Triassic basalt is characterized by spherulitic, variolitic or locally intersertal texture; porphyric plagioclase occurs rarely. An abundance of different kinds of hydrothermal infills is common. A high amount of microcrystalline material and the occurrence of hematite at almost all the localities are also typical. Calcite \pm chlorite \pm serpentine \pm hematite pseudomorphs after olivine were found in every locality and plagioclase shows most often skeletal crystal shape. Pyroxene occurs only rarely, as small laths.

In contrast Jurassic basalt in the Bükk Mts (Szarvaskó-type) is always characterized by a porphyry-intersertal texture. Both plagioclase and pyroxene occur as phenocrysts and in the groundmass as well. The amount of microcrystalline groundmass is very small and hematite generally does not occur. Hydrothermal infill is also very rare (Kiss 2008). Group C in the Rm-136 core belongs to this kind of basalt.

\section{Conclusions}

The study carried out in the quarries and deep wells of the Darnó Unit revealed that the Triassic basaltic blocks, which are preserved in a Jurassic mélange, represent distal parts of submarine lava flows. Comparison of the subsurface (well) data with the outcrops confirmed that no other volcanic facies occur at depth than those found at surface.

Macroscopic and microscopic evidences prove that Triassic basalt bears specific volcanological and textural characteristics which can be used to distinguish it from other submarine basaltic sequences (e.g. pillow basalts in ophiolitic suites), which occur in the same mélange. Moreover, four different groups could be distinguished within the Triassic basalt occurrences in the investigated outcrops. The studied basalt of the deep wells can be correlated with these groups. 


\section{Acknowledgements}

This work was supported by the Hungarian-Croatian Science and Technology Agreement Project No. 07/CRO (F. Molnár and L. A. Palinkaš) and the OTKA (HNSF) No. T 49633 and the HAESF Senior Fellowship (F. Molnár).

\section{References}

Balla, Z., Cs. Baksa, J. Földessy, L. Havas, I. Szabó 1980: The Tectonic setting of the Ophiolites in the Bükk Mountains (North Hungary). - Geol. Carpath., 31/4, pp. 465-493.

Balla, Z. 1987: A Bükk-hegység mezozoós tektonikája és kapcsolata a Nyugati-Kárpátokkal és a Dinaridákkal (Tectonics of the Bükkian (North Hungary) Mesozoic and relations to the West Carpathians and Dinarides). - Ált. Földt. Szemle, 22, pp. 13-54.

Buda, Gy., J. Kiss 1980: Comparison some chromite and titaniferous magnetite, ilmenite ore bearing ultrabasic-basic complexes. - UNESCO Int. Symp., Athens, 1, pp. 21-45.

Csontos, L. 1999: A Bükk-hegység szerkezetének fổbb vonásai (Structural outline of the Bükk Mts. N-Hungary). - Földt. Közl., 129/4, pp. 611-651.

Dosztály, L., S. Józsa 1992: Geochronological evaluation of Mesosoic formations of Darnó Hill at Recsk on the basis of radiolarians and K-Ar age dat. - Acta Geol. Hung., 35/4, pp. 371-393.

Downes, H., Gy. Pantó, P. Árkai, M.F. Thirlwall 1990: Petrology and geochemistry of Mesozoic igneous rocks, Bükk Mountains, Hungary. - Lithos, 24/3, pp. 201-215.

Gawlick, H.J., S. Kovács, J. Haas, S. Missioni, H. Suzuki, P. Ozsvárt, G. Kiss 2010: Middle Triassic and Middle Jurassic radiolarians from the Darnó ophiolitic mélange (NE Hungary) as northernmost part of the coherent north-south trending Neotethyan ophiolite belt. - Central. Eur. Geol., in this volume.

Haas, J., S. Kovács 2001: The Dinaric-Alpine connection - as seen from Hungary. - Acta Geol. Hung., 44/2-3, pp. 345-362.

Haas, J., S. Kovács, S. Karamata, M. Sudar 2010: Displaced South Alpine and Dinaridic elements in the Mid-Hungarian Zone. - Bulletin T. CXL Classe des sciences mathématiques et naturelles, Sciences naturelles, 46, pp. 81-103.

Harangi, Sz., Cs. Szabó, S. Józsa, Zs. Szoldán, E. Árva-Sós, M. Balla, I. Kubovics 1996: Mesozoic Igneous Suites in Hungary: Implications for Genesis and Tectonic Settings in the Northwestern Part of Tethys. - Int. Geol. Rev., 38, pp. 336-360.

Józsa, S. 1999: A darnó-hegyi óceánaljzati magmás kőzetek petrológiai-geokémiai vizsgálata (Petrological and geochemical analysis of the submarine igneous rocks of the Darnó Hill). manuscript, Eötvös Loránd University.

Kiss, G. 2008: A Darnói-egység mezozoós szubmarin vulkanizmusa és hidrotermás folyamatai, valamint ezek dinári kapcsolatai (Mesozoic submarine volcanism and related hydrothermal processes in the Darnó Unit and their connections to the Dinarides). - manuscript, Eötvös Loránd University.

Kiss, G., F. Molnár, L.A. Palinkaš 2008: Volcanic facies and hydrothermal processes in Triassic pillow basalts from the Darnó Unit, NE Hungary. - Geol. Croat., 61/2-3, pp. 385-394.

Kiss G., F. Molnár, L.A. Palinkaš, S. Kovács, H. Hrvatovic 2011: Correlation of Triassic advanced rifting related Neotethyan submarine basaltic volcanism of the Darnó Unit (NE Hungary) with some Dinaridic and Hellenidic occurrences on the basis of volcanological, fluid-rock interaction and geochemical characteristics. - Int. J. of Earth. Sci., in press.

Kiss, J. 1958: Ércföldtani vizsgálatok a Darnó-hegyen (Ore geological studies in the Darnó Hill). Földt. Közl., 88, pp. 27-41.

Kovács, S., J. Haas, G. Szebényi, Z. Gulácsi, P. Pelikán, G. B.-Árgyelán, S. Józsa, Á. Görög, P. Ozsvárt, Zs. Gecse, I. Szabó 2008: Permo-Mesozoic formations of the Recsk-Darnó Hill area: stratigraphy and structure of the pre-tertiary basement of the paleogene Recsk orefield. - In: Földessy, J., É. 
Hartai (Eds): Recsk and Lahóca Geology of the Paleogene Ore Complex, Geosciences, Publications of the University of Miskolc, Series A, Mining, 73, pp. 33-56.

†Kovács, S., J. Haas, P. Ozsvárt, L.A. Palinkaš, G. Kiss, F. Molnár, S. Józsa, Sz. Kövér 2010: Reevaluation of the Mesozoic complexes of Darnó Hill (NE Hungary) and comparisons with Neotethyan accretionary complexes of the Dinarides and Hellenides - preliminary data. Central. Eur. Geol., in this volume.

Kubovics, I. 1984: On the petrogenesis of the North Hungarian basic-ultrabasic magmatic rocks. Acta Geol. Hung., 27/1-2, pp. 163-189.

Kubovics, I., Cs. Szabó, Sz. Harangi, S. Józsa 1990: Petrology and petrochemistry of Mesozoic magmatic suites in Hungary and adjacent areas - an overview. - Acta Geod. Geoph. Mont. Hung., 25/3-4, pp. 345-371.

Mezôsi, J., Gy. Grasselly 1949: The occurrence of Native Copper in the Mátra Mountains at Bajpatak. - Acta Miner. Petrogr., III, pp. 44-47.

Papp, F. 1938: Notes sur les minerais de Recsk. - Földt. Közl., 68/7-9, pp. 208-214.

Palinkaš, A.L., V. Bermanec, M. Vrkljan, S. Medimorec 1998: Pillow lavas of Hruškovec, North Croatia, Rifting magmatism or dismembered ophiolitic sequence. - IGCP-369, Subp. 2, Final Session, Prague, pp. 84-85.

Palinkaš, A.L., T. Kolar-Jurkovšek, S. Borojevic, V. Bermanec 2000: Triassic rifting magmatism within Zagorje-Mid-Transdanubian zone, exemplified by pillow lavas of Hruškovec, Mt. Kalnik, N.Croatia. - In: Tomljenovic, B. et al. (Eds): PANCARDI 2000 meeting, Dubrovnik, 1.-3.10.2000, Geološke vijesti, 37, pp. 98-99.

Palinkaš, A.L., V. Bermanec, S. Borojevic Šoštaric, T. Kolar Jurkovšek, S. Strmic Palinkaš, F. Molnár, G. Kniewald 2008: Volcanic facies analysis of a subaqueous basalt lava-flow complex at Hruškovec, NW Croatia - evidence of advanced rifting in the Tethyan domain. - J. Volc. and Geotherm. Res., 178, pp. 644-656. 